\title{
FACTORS SHAPING THE PRICE OF GEODETIC WORKS IN REGARD TO THE NECESSITY OF ADAPTING LAND AND BUILDINGS REGISTER DATABASES TO THE REQUIREMENTS OF THE INSPIRE DIRECTIVE BASED ON THE EXAMPLE OF MAŁOPOLSKIE VOIVODESHIP
}

\author{
Aneta Dacko, Robert Szewczyk
}

\begin{abstract}
Summary
The development of the information society requires an appropriate infrastructure. One of its pillars is information on the boundaries of property ownership rights and information on buildings. According to Polish regulations, this information is included in the land and buildings register database $(\mathrm{EGiB})$. In case of poor quality and incomplete data that does not meet statutory requirements, a modernization of the database is necessary. Its proper execution requires large amount of work and money. For this reason in recent years many programs have been created, co-financed from EU funds, under which geodetic works are conducted, including the modernization of the land and buildings register database.

The paper presents an analysis of the main factors affecting the prices of modernization of land and buildings register in Małopolskie Voivodeship. For this purpose, data from tenders for the modernization of the EGIB database, published by public administration units operating this database, were used. The model containing multiple regressions allowed to estimate that the cost per unit of modernizing EGiB is impacted by: total plots/ha, the amount of buildings for measurement/ha and the type of maps in geodetic documentation.
\end{abstract}

\section{Keywords}

modernization of land records $\bullet$ prices of geodetic works $\bullet$ INSPIRE Directive

\section{Introduction}

Directive 2007/2/EC of the European Parliament and of the Council of 14 March 2007, titled the INSPIRE (Infrastructure for Spatial Information in Europe) Directive, imposes an obligation to provide access to information on the common European space. The European Commission (Directorates of Environment, ESTAT and JRC) has determined the basic legal solutions, thematic scope, operating principles and the program for creating infrastructure following above directive. Member States were required to transpose the INSPIRE Directive into their legal system. In Poland, this obligation is 
regulated by the Spatial Information Infrastructure Act, which entered into force on 7 June 2010. It introduces changes to the Act of 17 May 1989 - Geodetic and cartographic law. According to article 23, databases are to be established and maintained in the ICT system for an entire country covering spatial data sets and concerning land and buildings register (cadastre). Meeting this requirement involves carrying out comprehensive surveying works, often not only supplementing the record data resources, but also regulating the boundaries of real estate where there is incompatibility between the existing map materials and the actual state of affairs [Janus and Taszakowski 2015]. This problem is still relevant, especially in southern Poland, because until today many municipalities still have and operate on documents from the period of the Austrian Partition (maps 1:2880 of the Austrian cadastre). In addition, there are still some areas for which digital databases are only now being created.

\section{Methodological notes}

Data preparation and work on modernizing the database of land and buildings register (EGiB) are time consuming and require a lot of work and money [Gniadek et al. 2016, Hanus et al. 2018]. Such a task can be financed from the resources of local government units, as well as from EU funds ${ }^{1}$. The contractor for these tasks is selected in a tender process. Earlier, however, the county governor (who in accordance with Geodetic and Cartographic Law is obliged to maintain and modernize EGiB's data resources) must estimate and secure the budget for this purpose.

Currently, in the literature on the subject and in practice, there are no existing algorithms to perform an initial (approximate) estimation of the costs of this process.

The purpose of this study was an attempt to indicate factors and their impact on prices of modernization of the land and buildings register database in Małopolskie Voivodeship. The research covered 29 facilities from eight counties (Chrzanów, Tatra, Myślenice, Nowosądecki, Nowarski, Limanowski, Oświęcim, Suski) (Table 1) (Fig. 1), where tenders for the modernization of the EGIB databases were announced and decided.

The examined facilities are located mainly in the southwestern part of the voivodeship. The tasks specified in the tender process for these facilities were consistent and limited only to the modernization of EGiB. In the northern and eastern counties works related to the modernization of the $\mathrm{EGiB}$ database were combined with the creation of the GESUT and BDOT500 databases, and therefore they were not covered in the research.

The research material covered 29 facilities and was developed on the basis of documents included in announcements and results of tenders regarding the modernization of data contained in EGiB databases. Data for research was obtained from Public Information Bulletins of counties in the period of 2015-2019.

1 In recent years, in Małopolskie Voivodeship these tasks were realised under the programs: Zintegrowany System Informacji o Nieruchomościach (Integrated Real Estate Information System) and Cyfrowa Małopolska (Digital Lesser Poland). 
Table 1. List of examined facilities

\begin{tabular}{|c|c|c|c|c|}
\hline No. & Data & County & Municipality/Area & $\begin{array}{l}\text { Price } \\
\text { in PLN/ha }\end{array}$ \\
\hline 1 & 2016 & chrzanowski & Karniowice & 383.30 \\
\hline 2 & 2016 & tatrzański & Gliczarów Górny & 485.61 \\
\hline 3 & 2016 & myślenicki & Harbutowice & 234.15 \\
\hline 4 & 2017 & chrzanowski & Młoszowa & 293.85 \\
\hline 5 & 2017 & chrzanowski & Dulowa & 297.29 \\
\hline 6 & 2018 & suski & Juszczyn & 292.17 \\
\hline 7 & 2018 & suski & Krzeszów & 449.81 \\
\hline 8 & 2018 & suski & Tarnawa Górna & 409.68 \\
\hline 9 & 2018 & suski & Grzechynia & 415.49 \\
\hline 10 & 2018 & suski & Bieńkówka & 503.18 \\
\hline 11 & 2018 & myślenicki & Myślenice & 299.02 \\
\hline 12 & 2019 & myślenicki & Dobczyce & 270.64 \\
\hline 13 & 2019 & myślenicki & Sułkowice & 565.30 \\
\hline 14 & 2019 & nowosądecki & $\begin{array}{l}\text { Rytro municipality (Obłazy Ryterskie, Rytro, Roztoka } \\
\text { Ryterska, Sucha Struga) }\end{array}$ & 82.28 \\
\hline 15 & 2019 & nowotarski & Ochotnica Górna & 151.56 \\
\hline 16 & 2019 & nowotarski & Tylmanowa & 248.52 \\
\hline 17 & 2019 & nowotarski & Waksmund & 476.81 \\
\hline 18 & 2019 & limanowski & Dobra municipality (Chyszówki, Dobra) & 192.08 \\
\hline 19 & 2019 & limanowski & $\begin{array}{l}\text { Dobra municipality (Gruszowiec, Jurków, Półrzeczki, } \\
\text { Wilczyce) }\end{array}$ & 119.78 \\
\hline 20 & 2019 & limanowski & Laskowa municipality (Laskowa) & 254.48 \\
\hline 21 & 2019 & limanowski & $\begin{array}{l}\text { Laskowa municipality (Kamionka Mała, Krosna, Sechna, } \\
\text { Strzeszyce) }\end{array}$ & 178.27 \\
\hline 22 & 2019 & limanowski & Mszana Dolna municipality (Glisne, Olszówka, Raba Niżna) & 179.01 \\
\hline 23 & 2019 & limanowski & Mszana Dolna municipality (Kasinka Mała) & 254.95 \\
\hline 24 & 2019 & limanowski & Mszana Dolna municipality (Kasina Wielka) & 260.38 \\
\hline 25 & 2019 & limanowski & Mszana Dolna municipality (Łostówka, Mszana Górna) & 214.85 \\
\hline 26 & 2019 & limanowski & Mszana Dolna municipality (Lubomierz, Łętowe) & 135.89 \\
\hline 27 & 2019 & tatrzański & Witów & 217.30 \\
\hline 28 & 2019 & oświęcimski & $\begin{array}{l}\text { Kęty municipality (Bulowice, Łęki, Malec, Nowa Wieś, } \\
\text { Witkowice) }\end{array}$ & 131.62 \\
\hline 29 & 2019 & oświęcimski & Przeciszów municipality (Las, Piotrowice, Przeciszów) & 42.31 \\
\hline
\end{tabular}




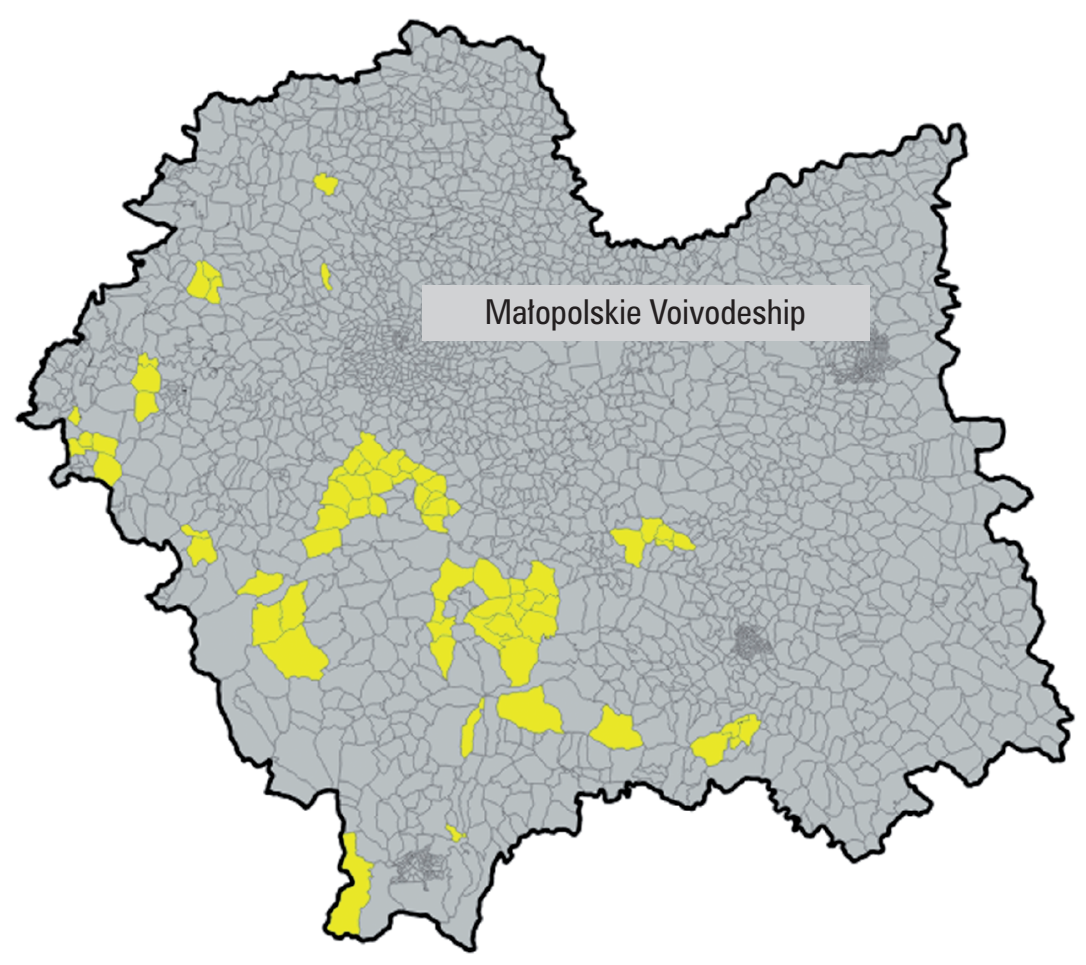

Fig. 1. Location of facilities in Małopolskie Voivodeship selected for research

\section{Modernization of the land and buildings register database}

In Poland, the provisions of the geodetic law impose on county administration and presidents of cities with county rights the obligation to maintain the EGIB database and keep the land registry survey up-to-date [Act 1989, Góźdź et al. 2014, Noszczyk and Hernik 2016, Wysocki 2003]. EGiB plays a very important role in the execution of local, regional and national tasks. The main goal of EGiB is to provide information on land, buildings and premises enabling the implementation of legal purposes, geodetic and legal processes, such as: division of real estate, expropriation of real estate, spatial planning, real estate management, real estate trading, calculation of taxes and subsidies of agricultural production and statistical purposes [Hycner 2004]. The EGiB database has been maintained and updated through constant entering modifications since its initiation [Mierzwa 2002, Aliab et al. 2012]. The law allows for a comprehensive update of the EGIB database by modernising it [Rozporząazenie 2001].

Modernising the EGIB database includes a number of formal and legal actions that adapt the existing EGiB to a state specified by statutory requirements. The aim of such actions is to present the ownership rights to land and buildings correctly, both in the descriptive and the graphic part of the database. As part of executive work, the contrac- 
tor is required to create digital data on border points, geodesic precincts, as well as land use and soil type delineations.

The cost of modernizing EGiB of individual facilities is mainly a sum of: the quality of materials collected in the resource and the amount of geodetic works necessary to bring the EGIB database into compliance with the conceptual model in the regulation on the land and buildings register.

The assessment of materials collected in the geodetic resource is carried out on the basis of an analysis of source data such as technical reports and map materials. Land registry surveys, which can be used for modernization, containing the results of geodetic and cartographic works performed for the needs of court and administrative proceedings, civil and legal actions and precinct soil classification. However, as part of the assessment of map materials, land registry map, soil classification map, and basic map are subject to review. The analysis of the above data and the data collected in a numerical database leads to several legal difficulties, because these data are inconsistent and often divergent. This is due to different quality of materials collected in a geodetic resource and a period of their creation, e.g. some tenders related to areas where a land registry map was drawn on the basis of cadastral maps of the former Austrian cadastre on a scale of 1: 2880, prepared in the Lviv system (KUL).

Factors characterizing the amount of geodetic works to be carried out at a facility during the modernization of EGiB are: the area of the facility, the number of plots, the number of registration units, the number of buildings, the number of border points and the percentage share of points in individual accuracy groups. This information is necessary to secure the timely execution of works, and thus, the employment of an appropriate number of geodetic teams that will perform both field measurements, as well as develop appropriate calculations, computer studies and outcome documents in the form of a geodetic survey, basic reports and prepare batch files to load the database.

The collected information on the quality of materials in the resource and the necessary activities that should be performed as part of the modernization of EGiB of a given facility by an authority running the EGIB database are the basis for estimating the required amount of financial resources. After securing the funds, the public procurement procedure is initiated in an open tender, in accordance with the Act of 29 January 2004. The description of the contract is included in the Specification of Essential Terms of the Order (SIWZ - Specyfikacja Istotnych Warunków Zamówienia). Annexes to the SIWZ contain the EGiB modernization project with a description of the facility whose database is to be modernized. The data contained in the SIWZ and annexes are the basis for estimating the cost of work by commercial companies participating in a tender.

\section{Modernization of land and buildings register - price factors}

For the purposes of works related to filling the data and modernizing EGiB, a set of features is defined with values of which may indicate the extent of work needed for this operation. Of course, this has an impact on the cost of an entire project. The following variables were adopted for detailed analyses of modernized units: the total number of 
border points, the number of border points to be determined in the field, the area of the facility, the number of total plots, the number of buildings to be measured, the number of surveys, the quality of archival materials (type of existing maps ${ }^{2}$ ), the price of the service. In order to determine the unit price for modernization, all these features were also calculated per unit area (1 hectare) (Table 2).

Table 2. Summary of data from tenders for selected facilities

\begin{tabular}{|c|c|c|c|c|c|c|c|c|}
\hline No. & $\begin{array}{c}\text { Price } \\
\text { in PLN/ha }\end{array}$ & Surveys/ha & Buildings/ha & Plots/ha & $\begin{array}{c}\text { Map } \\
\text { type }\end{array}$ & $\begin{array}{c}\text { Points } \\
\text { o/ha }\end{array}$ & Area & $\begin{array}{c}\text { Points } \\
\text { u/ha }\end{array}$ \\
\hline 1 & 383.30 & 383.30 & 1 & 1 & 5 & 0 & 14 & 542 \\
\hline 2 & 485.61 & 485.61 & 1 & 1 & 6 & 0 & 26 & 542 \\
\hline 3 & 234.15 & 234.15 & 1 & 1 & 3 & 1 & 20 & 1702 \\
\hline 4 & 293.85 & 293.85 & 1 & 1 & 3 & 1 & 8 & 1300 \\
\hline 5 & 297.29 & 297.29 & 1 & 1 & 2 & 1 & 7 & 753 \\
\hline 6 & 292.17 & 292.17 & 0 & 0 & 6 & 0 & 19 & 2523 \\
\hline 7 & 449.81 & 449.81 & 1 & 0 & 8 & 0 & 21 & 1554 \\
\hline 8 & 409.68 & 409.68 & 0 & 0 & 5 & 0 & 14 & 537 \\
\hline 9 & 415.49 & 415.49 & 1 & 1 & 5 & 0 & 18 & 1832 \\
\hline 10 & 503.18 & 503.18 & 0 & 1 & 9 & 0 & 24 & 2047 \\
\hline 11 & 299.02 & 299.02 & 2 & 0 & 3 & 1 & 18 & 10698 \\
\hline 12 & 270.64 & 270.64 & 1 & 1 & 2 & 1 & 14 & 5343 \\
\hline 13 & 565.30 & 565.30 & 2 & 1 & 4 & 1 & 20 & 2300 \\
\hline 14 & 82.28 & 82.28 & 0 & 0 & 1 & 1 & 7 & 4193 \\
\hline 15 & 151.56 & 151.56 & 0 & 0 & 2 & 0 & 8 & 5272 \\
\hline 16 & 248.52 & 248.52 & 1 & 1 & 4 & 0 & 12 & 3514 \\
\hline 17 & 476.81 & 476.81 & 1 & 1 & 8 & 0 & 22 & 1531 \\
\hline 18 & 192.08 & 192.08 & 1 & 1 & 4 & 1 & 18 & 3093 \\
\hline 19 & 119.78 & 119.78 & 1 & 0 & 3 & 1 & 14 & 4590 \\
\hline 20 & 254.48 & 254.48 & 1 & 1 & 2 & 1 & 17 & 2117 \\
\hline 21 & 178.27 & 178.27 & 1 & 1 & 1 & 1 & 16 & 2677 \\
\hline 22 & 179.01 & 179.01 & 1 & 0 & 3 & 1 & 16 & 3408 \\
\hline 23 & 254.95 & 254.95 & 1 & 1 & 5 & 1 & 23 & 2639 \\
\hline
\end{tabular}

2 For the Austrian cadastre maps, the value 0 was adopted, and for the remaining ones 1. 


\begin{tabular}{|c|c|c|c|c|c|c|c|c|}
\hline 24 & 260.38 & 260.38 & 1 & 1 & 5 & 1 & 23 & 2584 \\
\hline 25 & 214.85 & 214.85 & 1 & 1 & 4 & 1 & 20 & 3246 \\
\hline 26 & 135.89 & 135.89 & 1 & 0 & 2 & 1 & 10 & 5132 \\
\hline 27 & 217.30 & 217.30 & 0 & 0 & 3 & 0 & 7 & 7018 \\
\hline 28 & 131.62 & 131.62 & 2 & 0 & 3 & 1 & 12 & 4551 \\
\hline 29 & 42.31 & 42.31 & 1 & 0 & 3 & 1 & 13 & 3545 \\
\hline
\end{tabular}

Information from tenders were supplemented with the date and site of modernization works. For the dataset prepared in this way, a multiple regression model was built, accompanied with a preliminary assessment of the significance of individual features. Using the progressive regression procedure, four statistically significant factors shaping the unit prices of surveying works were identified: the number of surveys/ha, the number of buildings to be measured/ha, the number of total parcels/ha and the type of maps. The matched $\mathrm{R}$ square was 0.90 and the standard error was 67.9. In the next step, an attempt was made to reject outliers. By analysing Cook's distance ${ }^{3}$, these observations were left out from the model, for which the values of this statistic clearly stood out from the entire dataset. The standard error fell to 30 (that is, we can be mistaken for an average price of PLN 30 per hectare) and the adjusted R square increased to 0.99 (Table 3). The 'number of surveys/ha' variable was excluded from the model as it lost its statistical significance after removing outliers. The developed model allowed determining the relationship between the number of total plots/ha $(b)$, the number of buildings to be measured/ha $(b)$ and the type of maps $(m)$ and the unit cost of modernizing EGiB (y) described by a multiple regression formula (1).

$$
y=35 \cdot d z+209 \cdot b-51 \cdot m
$$

The coefficients for variables indicate the unit value of a particular factor in the zloty (PLN) and allow to estimate the unit cost of upgrading the facility.

Table 3. Summary of dependent variable regression: price/ha

\begin{tabular}{|c|c|c|c|c|c|c|}
\hline \multirow{2}{*}{$\begin{array}{c}\begin{array}{c}\text { Number of } \\
\text { observations } \\
\text { N }=24\end{array}\end{array}$} & \multicolumn{6}{|c|}{$\begin{array}{c}\mathrm{R}=0.995, \mathrm{R}^{2}=0.990, \text { Ap. } \mathrm{R}^{2}=0.988, \mathrm{~F}(3.21)=705, \mathrm{p}<0.000 \\
\text { Standard error estimation: } 30\end{array}$} \\
\hline & $\beta$ & Standard error $\beta$ & b & Standard error $b$ & $t(21)$ & $\mathrm{p}$ \\
\hline Plots/ha & 0.51 & 0.04 & 34.73 & 2.73 & 12.73 & 0.00 \\
\hline Buildings/ha & 0.62 & 0.05 & 209.02 & 16.49 & 12.67 & 0.00 \\
\hline Map type & -0.14 & 0.03 & -51.32 & 11.17 & -4.59 & 0.00 \\
\hline
\end{tabular}

3 This is a measure of the degree of change in regression factors if a particular case was to be left out from the calculation of coefficients. 
The model proved to be significant $\left(\mathrm{F}_{(3.21)}=705.06 ; \mathrm{p}<0.000\right)$, and all predictors explained a total of $99 \%$ of the dependent variable (revised $\mathrm{R}^{2}=0.99$ ). Three factors had a significant impact on the unit price: the total parcels/ha $(\beta=0.51 ; \mathrm{t}=12.73 ; \mathrm{p}=0.00)$; the number of buildings to measure/ha $(\beta=0.62, \mathrm{t}=12.67, \mathrm{p}=0.00)$ and the map type $(\beta=-0.14, \mathrm{t}=-4.59, \mathrm{p}=0.00)$.

\section{Summary}

According to the studies, there is a relative consistency between the different results of tenders. One of the reasons for this is a very limited number of companies that can carry out such tasks and thus take part in tenders. This limitation relates to the need to recruit a large number of professionals with surveying rights in this field and the need to provide long term resources. Therefore, only large surveying companies with good financial shape and a large number of specialised employees can undertake tasks related to the modernisation of the EGIB database.

In conclusion, it should be noted that, in view of the limited market for contractors of such services and the highly formalised structure of the activities carried out in this regard, it is possible to forecast the prices of the work related to the modernisation of EGiB. The mathematical relationships described above can be useful both for commercial companies competing in tenders, but also for public administrations to secure adequate funds for the execution of such operations. It is worth adding that costs of this kind of surveying work is practically impossible to accurately estimate as they involve purely human factors.

\section{References}

Aliab Z., Tuladharb A., Zevenbergen J. 2012. An integrated approach for updating cadastral maps in Pakistan using satellite remote sensing data. International Journal of Applied Earth Observation and Geoinformation, 18, August, 386-398.

Dyrektywa Parlamentu Europejskiego i Rady Nr 2007/2/WE z dnia 14 marca 2007 r. ustanawiająca infrastrukturę informacji przestrzennej we Wspólnocie Europejskiej (INSPIRE) (Dz. Urz. UE L 108 z 25.04.2007 z późn. zm.).

Góźdź K., Parzyński Z., Radzio W. 2014. Polski kataster nieruchomości jako element INSPIRE. Roczn. Geomatyki, XII, 1(63), 51-66.

Gniadek J., Janus J., Ostrowska R. 2016. Rolnicza przestrzeń produkcyjna - ocena i możliwości jej poprawy na przykładzie Rudnik Stróży. Infrastruktura i Ekologia Terenów Wiejskich, II/1, 335-347.

Hanus P., Pęska-Siwik A., Szewczyk R. 2018. Spatial analysis of the accuracy of the cadastral parcel boundaries. Computers and Electronics in Agriculture, 144, 9-15.

Hycner R. 2004. Podstawy katastru. Wydawnictwa AGH.

Janus J., Taszakowski J. 2015. The idea of ranking in setting priorities for land consolidation works. Geomatics, Landmanagement and Landscape, 1, 31-43.

Mierzwa W. 2002. Problemy modernizacji ewidencji gruntów na terenach byłego katastru austriackiego. Zesz. Nauk. AGH, ser. Geodezja, 8(2), 323-330. 
Noszczyk T., Hernik J. 2016. Kompleksowa modernizacja ewidencji gruntów i budynków. Acta Sci. Pol., ser. Formatio Circumiectus, 15 (1), 3-17.

Rozporządzenie Ministra Rozwoju Regionalnego i Budownictwa z dnia 29 marca 2001 r. w sprawie ewidencji gruntów i budynków (Dz. U. z 2015 r., poz. 542 z późn. zm.).

Ustawa z dnia 17 maja 1989 r. - Prawo geodezyjne i kartograficzne (Dz. U. z 2019 r., poz. 725 $\mathrm{z}$ późn. $\mathrm{zm}$.).

Ustawa z dnia 29 stycznia 2004 r. - Prawo zamówień publicznych (Dz. U. z 2019 r., poz. 1843).

Ustawa z dnia 4 marca 2010 r. o infrastrukturze informacji przestrzennej (Dz. U. z 2020 r., poz. 177.

Wysocki P. 2003. Optymalizacja metody modernizacji ewidencji gruntów i budynków. Arch. Fotogrametrii, Kartografii i Teledetekcji, 13 A, 277-283.

Dr inż. Aneta Dacko

Uniwersytet Rolniczy w Krakowie

Katedra Geodezji Rolnej, Katastru i Fotogrametrii

30-198 Kraków, ul. Balicka 253a

e-mail: aneta.dacko@urk.edu.pl

ORCID: 0000-0003-1470-5442

Dr inż. Robert Szewczyk

Uniwersytet Rolniczy w Krakowie

Katedra Geodezji Rolnej, Katastru i Fotogrametrii

30-198 Kraków, ul. Balicka 253a

e-mail: robert.szewczyk@urk.edu.pl

ORCID: 0000-0003-0885-8610 